\title{
Replacement of corn with babassu mesocarp flour in balanced rations for broilers in the period from 1 to 21 days ${ }^{1}$
}

\section{Substituição do milho pela farinha do mesocarpo de babaçu em rações balanceadas para frangos de corte de 1 a 21 dias de idade ${ }^{1}$}

\author{
Flávia Luzia Rodrigues Fonseca ${ }^{2 *}$; Jefferson Costa de Siqueira ${ }^{3}$; Roberta Gomes \\ Marçal Vieira Vaz ${ }^{4}$; Kênia Ferreira Rodrigues ${ }^{4}$; Gerson Fausto da Silva ${ }^{4}$; Ana \\ Cláudia Gomes Rodrigues Neiva ${ }^{4}$; Mônica Calixto da Silva ${ }^{2}$; Joana Patrícia Lira de \\ Sousa $^{5}$; Iberê Pereira Parente ${ }^{5}$ Carla Fonseca Alves ${ }^{6}$; Rosiane Aires Luz ${ }^{7}$
}

\begin{abstract}
The objective of this study was to evaluate the technical and economic feasibility of partial replacement of corn with babassu mesocarp flour in diets for broilers from one to 21 days of age. Two hundred male day-old chicks, from the Cobb $500^{\circledR}$ line, were distributed in a completely randomized design with four treatments $(0 \%, 10 \%, 20 \%$ and $30 \%$ replacement of maize flour with the babassu mesocarp) and five replicates were used comprising ten birds. Were evaluated performance (weight gain, feed intake, feed conversion and water intake), organ biometrics, metabolizability coefficients of dry matter (MCDM), crude protein (MCCP) and gross energy (MCGE) and cost of feeding diets containing babassu mesocarp flour (BMF). It was observed that the substitution of corn with BMF negatively influenced $(\mathrm{P}<0.05)$ weight gain, feed conversion and body weight at 21 days of age. The MCDM and MCGE of the diets decreased with increasing level of substitution of corn for BMF. The levels of substitution of corn with BMF did not affect $(\mathrm{P}>0.05)$ the relative weights of the carcass, bursa, spleen, heart, gizzard or liver, nor the relative weight or length of the small intestine. The lower cost of feed per kg of weight gain was obtained with the diet containing $10 \%$ corn replacement with BMF, which resulted in a higher gross margin in relation to food. The replacement of corn with BMF in diets for broilers from one to 21 days of age proved to be technically feasible in $10 \%$.
\end{abstract}

Key words: Coefficient of metabolizability, feeding cost, productive performance

\section{Resumo}

Objetivou-se neste trabalho avaliar a viabilidade técnica e econômica da substituição parcial do milho pela farinha do mesocarpo do babaçu em rações para frangos de corte de um a 21 dias de idade. Foram

1 Parte da Dissertação de Mestrado do primeiro autor.

2 Discentes do Curso de Doutorado do Programa de Pós-Graduação em Ciência Animal Tropical, Universidade Federal de Tocantins, UFT, Araguaína, TO, Brasil.E-mail: flrf@outlook.com; monicalixto_@hotmail.com

3 Prof. Dr., Universidade Federal do Maranhão, UFMA, Centro de Ciências Agrárias e Ambientais, Chapadinha, MA, Brasil. Bolsista FAPEMA. E-mail: jcsiqueira@ufma.br

4 Profs. Drs., Dept ${ }^{\text {}}$ de Zootecnia da Escola de Medicina Veterinária e Zootecnia, UFT, Araguaína, TO, Brasil. E-mail: betagmvvaz@ yahoo.com.br; rodrigueskf@mail.uft.edu.br; aclaudianeiva@gmail.com; gerson@mail.uft.edu.br

5 Drs. em Ciência Animal Tropical, Universidade Federal de Tocantins, UFT, Araguaína, TO, Brasil. E-mail: jp-zoot@hotmail. com; iberepereira@hotmail.com

6 Discente do Curso de Mestrado do Programa de Pós-Graduação em Ciência Animal Tropical, UFT, Araguaína, TO, Brasil. E-mail: carlafazoo@hotmail.com

7 Zootecnista da Ruraltins, Araguaína, TO, Brasil. E-mail: rosianeaires-10@hotmail.com

* Author for correspondence 
utilizados 200 pintos machos de um dia, da linhagem Cobb $500^{\circledR}$, distribuídos em delineamento inteiramente casualizado, com quatro tratamentos $(0,10,20$ e $30 \%$ de substituição do milho pela farinha do mesocarpo do babaçu) e cinco repetições composta por dez aves. Foram avaliados o desempenho (ganho de peso, consumo de ração, conversão alimentar e ingestão de água), biometria dos órgãos, os coeficientes de metabolizabilidade da matéria seca (CMMS), da proteína bruta (CMPB) e da energia bruta (CMEB) e o custo da alimentação de dietas contendo farinha do mesocarpo de babaçu (BMF). Observou-se que a substituição do milho pela BMF influenciou negativamente $(\mathrm{P}<0,05)$ o ganho de peso, a conversão alimentar e o peso das aves aos 21 dias de idade. Os FMB e CMEB das rações reduziram com o aumento do nível de substituição do milho pela FMB. Os níveis de substituição do milho pela BMF não afetaram $(\mathrm{P}>0,05)$ os pesos relativos da carcaça, bursa, baço, coração, moela e fígado, nem o peso relativo ou comprimento do intestino delgado. O menor custo com ração por kg de GP foi obtido com a dieta contendo $10 \%$ de substituição do milho pela BMF, o que resultou na maior margem bruta em relação à alimentação. A substituição do milho pela farinha do mesocarpo do babaçu em rações para frangos de corte de um a 21 dias de idade mostrou-se tecnicamente viável em até 10\%.

Palavras-chave: Coeficiente de metabolização, custo com alimentação, desempenho produtivo

\section{Introduction}

Feed is the major cost in the production of broilers characterized by a heavy reliance on corn and soybean meal as the main sources of energy and protein in diets (JESUS JUNIOR et al., 2007). Strong seasonal changes in the availability of grains composing the poultry feed and fluctuations in their market values raise the prices of poultry products.

The use of alternative foods arising from the process of industrialization of the babassu coconut mesocarp as flour and babassu pie has aroused interest in the field of animal nutrition. Many researches in feeding broilers have been performed (CARNEIRO et al., 2009; CRUZ et al., 2013; SANTOS NETA et al., 2011) demonstrating that these coconut derivatives can be sources of nutrients that reduce feed costs, particularly in the off-season when the prices of corn and soybean meal increase.

Babassu mesocarp flour is considered an energetic food containing $3687 \mathrm{Kcal} / \mathrm{kg}$ gross energy, 52-71\% starch (CAVALCANTE NETO, 2012; PAVLAK et al., 2007; ROSTAGNO et al., 2011) and has anti-inflammatory analgesic therapeutic properties and an absence of toxicity (AMORIM et al., 2006;. BARROQUEIRO et al., 2011; SANTOS et al., 2012).

Cruz et al. (2013) evaluated the effects of increasing the levels of babassu mesocarp flour $(0 \%$,
$6 \%, 12 \%$ and $18 \%$ ) on feed intake, weight gain, feed conversion, carcass yield and blood proteins of broilers with 8-21 days of age, and found that the addition of up to $12 \%$ of babassu mesocarp flour in feed does not compromise performance.

Given the above, the objective was to assess the levels of substitution of corn with babassu mesocarp flour $(0 \%, 10 \%, 20 \%$ and $30 \%)$ in balanced rations for broilers aged $1-21$ days of age.

\section{Materials and Methods}

The experiment was conducted at the Poultry Section of the Veterinary Medicine and Animal Science School at the Federal University of Tocantins, in Araguaína - TO from March 22 to April 11, 2012.

Two hundred one-day-old broiler chicks, male Cobb $500 \AA$ lineage, with an initial average weight of $38 \mathrm{~g}$ were used. These were housed in experimental shed masonry covered with a concrete floor covered with babassus straw, concrete floor and containing cages of $1.0 \times 1.0 \times 0.5 \mathrm{~m}$ with trough feeders and pressure cup drinkers. The supply feeders and waterers were cleaned and filled twice a day to ensure free access to water and feed throughout the experimental period.

Until the 14th day of life the broilers were artificially heated using incandescent lamps (60W) 
installed inside the cages. The study was conducted following the guidelines of the Federal University of Tocantins Ethics Committee and approved by the bioethics committee under the number 001308 23101/2013-62.

Environmental conditions were monitored and recorded daily using dry bulb thermometers, wet bulb thermometers and maximum/minimum thermometers placed at intermediate height on the cages allowing the calculations of average maximum temperatures, and minimum relative humidity within the premises during the experimental period.
Broilers were distributed in a completely randomized design (CRD) with four treatments $(0 \%, 10 \%, 20 \%$ and $30 \%$ replacement of maize flour with babassu mesocarp) and five replicates of ten broilers per experimental unit.

The experimental diets were calculated taking into account the chemical composition of the ingredients (Table 1) and the nutritional requirements of the birds in accordance with the recommendations of Rostagno et al. (2011) (Table 2).

Table 1. Composition of the main ingredients used in the formulation of experimental diets (as fed basis).

\begin{tabular}{lccc}
\hline Nutrient & Corn & Soybean meal & Babassu Mesocarp Flour \\
\hline Gross energy (kcal/kg) & $4069^{1}$ & $4133^{1}$ & $3777^{1}$ \\
Metabolizable energy (kcal / kg) & $3381^{3}$ & $2254^{3}$ & $2027^{2}$ \\
Crude protein (\%) & $7.92^{1}$ & $51.57^{1}$ & $3.64^{1}$ \\
Calcium (\%) & $0.03^{3}$ & $0.24^{3}$ & $0.16^{1}$ \\
Available phosphorus (\%) & $0.06^{3}$ & $0.22^{3}$ & $0.02^{1.4}$ \\
Lysine (\%) & $0.20^{3}$ & $2.57^{3}$ & ----- \\
Digestible methionine (\%) & $0.16^{3}$ & $0.55^{3}$ & ----- \\
Digestible threonine (\%) & $0.29^{3}$ & $1.57^{3}$ & ---- \\
Sodium (\%) & $0.02^{3}$ & $0.02^{3}$ & ---- \\
Potassium (\%) & $0.29^{3}$ & $1.83^{3}$ & ---- \\
Chlorine (\%) & $0.06^{3}$ & $0.05^{3}$ & ---- \\
Crude fibre (\%) & $1.806^{1}$ & $6.49^{1}$ & $25.9^{1}$ \\
NDF (\%) & $11.93^{3}$ & $19.14^{1}$ & $45.61^{1}$ \\
FDA (\%) & $3.38^{3}$ & $7.52^{1}$ & $29.95^{1}$ \\
\hline
\end{tabular}

${ }^{1}$ Analyses made at Laboratório de Nutrição Animal da Escola de Medicina Veterinária e Zootecnia da Universidade Federal do Tocantins.

${ }^{2}$ Santos Neta (2010).

${ }^{3}$ Rostagno et al. (2011).

${ }^{4}$ Estimated values considering $33 \%$ availability of (phosphorus total $=0.066 \%$ ).

The variables analysed were feed intake (FI) weight gain (WG) feed conversion (FC), weight at 21 days (W21d), water intake (IH2O), organ biometrics (heart, liver, gizzard, bursa, spleen and small intestine), metabolizability coefficients of dry matter (MCDM), crude protein (MCCP) and gross energy (MCGE), and the cost of feeding diets containing babassu mesocarp flour (BMF).

To obtain the weight gain, broilers were weighed at the beginning and at the end of the experimental period. Feed intake was calculated considering the amount of feed placed in the feeders and the amount of leftovers, and the feed conversion ratio of feed intake and weight gain of the birds.

To record water intake a graduated cylinder with a capacity of $1 \mathrm{~L}$ was used. Water consumption of each experimental unit was recorded daily at 08:00 and 16:00. The water was collected from the trough before being discarded. Feed leftovers and excreta were separated using a 0.05 mesh sieve. 
An additional trough was placed inside the shed to estimate water loss by evaporation. Water intake was determined by summing the volumes delivered, discounting evaporative losses at the end of the phase.

Table 2. Composition of experimental diets containing increasing levels of substitution of corn with babassu mesocarp flour for broilers from 1 to 21 days old.

\begin{tabular}{|c|c|c|c|c|}
\hline \multirow[t]{2}{*}{ Ingredients } & \multicolumn{4}{|c|}{$\begin{array}{l}\text { Levels of substitution of corn with } \\
\text { babassu mesocarp flour }(\%)\end{array}$} \\
\hline & 0 & 10 & 20 & 30 \\
\hline Corn & 55.038 & 49.534 & 44.030 & 38.527 \\
\hline Soybean meal $(45 \%)$ & 35.582 & 35.582 & 35.582 & 35.582 \\
\hline Babassu mesocarp flour & 0.000 & 5.504 & 11.008 & 16.511 \\
\hline Dicalcium phosphate & 1.607 & 1.625 & 1.642 & 1.659 \\
\hline Soybean oil & 0.716 & 2.135 & 3.554 & 4.973 \\
\hline Limestone & 0.888 & 0.859 & 0.830 & 0.800 \\
\hline Common salt & 0.439 & 0.443 & 0.447 & 0.451 \\
\hline DL-Methionine & 0.324 & 0.342 & 0.361 & 0.379 \\
\hline L-Lysine $\mathrm{HCl}$ & 0.297 & 0.312 & 0.326 & 0.341 \\
\hline L-Threonine & 0.109 & 0.125 & 0.142 & 0.159 \\
\hline Mineral supplement ${ }^{1}$ & 0.250 & 0.250 & 0.250 & 0.250 \\
\hline Vitamin supplement $^{1}$ & 0.250 & 0.250 & 0.250 & 0.250 \\
\hline Starch & 4.500 & 3.040 & 1.580 & 0.119 \\
\hline Total & 100 & 100 & 100 & 100 \\
\hline \multicolumn{5}{|l|}{ Calculated nutritional composition } \\
\hline $\mathrm{ME}(\mathrm{Kcal} / \mathrm{kg})$ & 2950 & 2950 & 2950 & 2950 \\
\hline Crude protein $(\%)$ & 22.7 & 22.5 & 22.2 & 22.00 \\
\hline Calcium (\%) & 0.870 & 0.870 & 0.870 & 0.870 \\
\hline Available phosphorus (\%) & 0.409 & 0.409 & 0.409 & 0.409 \\
\hline Digestible lysine (\%) & 1.258 & 1.258 & 1.258 & 1.258 \\
\hline Methionine + digestible cystine $(\%)$ & 0.896 & 0.896 & 0.896 & 0896 \\
\hline Digestible methionine (\%) & 0.616 & 0.625 & 0.635 & 0.644 \\
\hline Digestible threonine (\%) & 0.825 & 0.825 & 0.825 & 0.825 \\
\hline Sodium (\%) & 0.215 & 0.215 & 0.215 & 0.215 \\
\hline Potassium (\%) & 0.819 & 0.803 & 0.787 & 0.770 \\
\hline Crude fibre $(\%)$ & 3.303 & 4.633 & 5.963 & 7.293 \\
\hline Neutral detergent fibre (\%) & 13.378 & 15.231 & 17.085 & 18.939 \\
\hline Acid detergent fibre (\%) & 4.536 & 5.998 & 7.461 & 8.923 \\
\hline
\end{tabular}

${ }^{1}$ Composition/ton: Folic acid 120 mg; Cobalt 179mg; Copper 2688mg; Hill 108 g; Iron 11 g; Iodine 537 mg; Lincomycin $800 \mathrm{mg}$; Manganese 31 g; Matter mineral 350 g; Niacin 6000 mg; Calcium Pantothenate 1920 mg; Salinomycin 12 g; Selenium 54 mg; Humidity 80 g; Vitamin A 1,500 IU; Vitamin B1 300 mg; Vitamin B12 2800 mg; Vitamin B2 960 mg; Vitamin B6 450mg; Vitamin D3 300 IU; Vitamin E 3000 IU; Vitamin H 20 mg; Vitamin K 480 mg; Zinc 22 g. 
Total collections of excreta from 17th to 20th experimental day were done as described by Sakomura and Rostagno (2007) to the calculation of the coefficients (MCDM), (MCCP) and (MCGE) of the experimental diets.

Trays covered with plastic sheeting were placed under the experimental cage to allow the collection of excreta, which was done twice a day at 08:00 and 16:00. Once collected, the excreta were placed in plastic bags identified by repetition and frozen. The excreta of each experimental unit were thawed at room temperature and homogenized at the end of the experiment. An amount of $400 \mathrm{~g}$ was with drawn from the total excreta of each experimental unit and then wrapped in a forced-air oven at $55{ }^{\circ} \mathrm{C}$ for 72 hours to promote pre-drying and to determine the weight of the dry sample in air. Samples of the experimental diets and excreta were sent to the laboratory of Tropical Animal Science, Federal University of Tocantins to determine dry matter (DM), crude protein (CP) and gross energy (GE) according to Silva e Queiroz (2002).

For the calculations of the coefficients of apparent metabolizability (CAM) of the nutrients (MCDM, MCCP and MCGE), the equation described by Sakomura and Rostagno (2007) was used:

$$
\text { CAM }(\%)=\frac{(\text { Nut ing }- \text { Nut exc })}{\text { Nut ing }} \times 100
$$

Where Nut ing = intake of DM, CP or GE; Nut exc $=$ excretion of DM, CP or GE. At 21 days of age two broilers from each plot with near average $( \pm 5 \%)$ body weight underwent fasting for 12 hours and were killed by cervical dislocation. They then underwent procedures for bleeding, scalding, plucking and gutting. The edible viscera (gizzard, heart and liver), lymphoid organs (bursa and spleen) and the small intestine were collected during evisceration and cleaned and dried using paper towel and weighed separately on a precision scale paper. All the fat attached, content and the coilin membrane were removed from the gizzard. The small intestine was meausred and weighed from the beginning of the duodenum to the ileocaecal junction.
The relative weight of the plucked and eviscerated carcass was calculated based on he weight of the broilers fasting. The relative weights of edible offal lymphoid organs and the small intestine were obtained from the lucked and eviscerated carcass.

Data for the variables evaluated were submitted to Normality (Cramer Von Mises) and homoscedasticity (Levene) tests. Once these assumptions were met the variables were subjected to analysis of variance using the statistical model:

$\mathrm{Y}_{\mathrm{ij}}=\mu+\mathrm{NS}_{\mathrm{i}}+\mathrm{e}_{\mathrm{ij} ;}$ com $\mathrm{i}=1,2,3,4 ; \mathrm{j}=1,2,3,4,5$, Where Yij $=$ observed value for the variable of interest in the birds of the $\mathrm{j}$-th repetition receiving the i-iésimo level of replacement of corn with babassu mesocarp flour; $\mu=$ the overall mean effect; $\mathrm{NSi}=$ the effect of the i-iésimo level of replacement of corn with babassu mesocarp flour; eij = experimental error.

Variables whose effects of replacing the corn with babassu mesocarp flour were detected by analysis of variance $(\mathrm{p}=0.05)$ were subjected to regression analysis using polynomial models of first or second order considering the level of substitution replacing the corn with babassu mesocarp flour as an independent variable. To check the fit of the equation the significance of the ' $F$ ' test for the models, the significance of the ' $t$ ' test for the parameters $(\beta 0, \beta 1$ and $\beta 2)$ of the models and the coefficients of determination $\left(\mathrm{R}^{2}=\right.$ Model SQ/SQ treatment) were considered.

The treatment means were compared by Student Newman Keuls (SNK) considering a significance level equal to or less than $5 \%$. Statistical analyses were carried out using the SAS 9.0 software (2002).

For the calculation of feed costs, it was considered that the animals used throughout the experimental period were raised under the same conditions (facilities, manpower, equipment, etc.) with only the diets provided differing. Thus, only the value of the expenditures on feeding the chickens was considered to quantify the cost difference between treatments. 
The economic efficiency of the experimental diets was determined with the cost per $\mathrm{kg}$ of chicken feed made as follows:

$$
\mathrm{CWG}_{\mathrm{i}}=\left(\mathrm{AF}_{\mathrm{i}} \times \mathrm{PF}_{\mathrm{i}}\right) / \mathrm{WG} \text {; com } \mathrm{i}=1,2,3,4,
$$

Where CWGi $=$ feed cost per $\mathrm{kg}$ weight gain $(\mathfrak{f} /$ $\mathrm{kg}$ ) produced with the use of the i-iésimo level of substitution of corn with babassu mesocarp flour; $\mathrm{AFi}$ = amount of feed $(\mathrm{kg})$ consumed in i-iésimo level of replacement of corn with babassu mesocarp flour; $\mathrm{PFi}=$ price of feed $(£ / \mathrm{kg})$ containing the i-iésimo level of replacement of corn with babassu mesocarp flour; and WGi = weight gain $(\mathrm{kg})$ of the birds receiving the i-iésimo level of replacement of corn with babassu mesocarp flour. The gross margin per $\mathrm{kg}$ of chicken on each level of substitution of corn with babassu mesocarp flour in diets was calculated by the expression:

$$
\mathrm{GM}_{\mathrm{i}}=\mathrm{SPC}-\mathrm{CWG}_{\mathrm{i}}
$$

Where $\mathrm{GMi}=$ gross margin per $\mathrm{kg}$ of chicken $(\mathfrak{f})$ obtained using the i- ésimo level of substitution of corn with babassu mesocarp flour; SPC = selling price of live chicken $(£ \mathrm{~kg})$; and $\mathrm{CWG}=$ feed cost per $\mathrm{kg}$ weight gain $(£ / \mathrm{kg}$ ) produced with the use of the i-ésimo level of substitution of corn with babassu mesocarp flour.

\section{Results and Discussion}

The minimum, average and maximum temperatures inside the premises within one to 14 days of the birds' age were $21.6 ; 25.3 ; 29.0$, respectively, with an average relative humidity of $58 \%$. In the experimental period 15-21 days of age it was $21.8 ; 26.2 ; 30.5$, respectively, with an average relative humidity of $57 \%$.

Temperatures and relative humidity recorded during the experimental period are consistent with the recommendations for the broiler strain used, which advocate that the ambient temperature should be around $33{ }^{\circ} \mathrm{C}$ in the first day, reducing gradually to reach $26{ }^{\circ} \mathrm{C}$ corresponding to the third week of the birds life' (OLIVEIRA et al., 2006).

It was observed that the substitution of maize flour with the babassu mesocarp flour (BMF) influenced $(\mathrm{P}<0.05)$ weight gain (WG), feed conversion (FC) and the weight of the birds at 21 days (P21d), but there was no influence $(\mathrm{P}>0.05)$ on feed intake $(\mathrm{FI})$ or water intake (IH2O) (Table 3).

Table 3. Mean values of feed intake (FI), weight gain (WG), feed conversion (FC), water intake (IH2O) and weight at

\begin{tabular}{|c|c|c|c|c|c|c|}
\hline \multirow{2}{*}{ Variables } & \multicolumn{4}{|c|}{ Levels of substitution of corn for babassu flour mesocarp (\%) } & \multirow{2}{*}{$\mathrm{CV}^{1}$} & \multirow{2}{*}{$\mathrm{P}>\mathrm{F}^{2}$} \\
\hline & 0 & 10 & 20 & 30 & & \\
\hline FI (g) & 1073.20 & 1061.00 & 1054.48 & 1041.26 & 3.39 & 0.5721 \\
\hline $\mathrm{WG}(\mathrm{g})^{4}$ & $713.12^{\mathrm{a}}$ & $710.44^{\mathrm{a}}$ & $653.61^{\mathrm{b}}$ & $644.28^{b}$ & 3.96 & 0.0009 \\
\hline $\mathrm{FC}(\mathrm{g} / \mathrm{g})^{4}$ & $1.507^{\mathrm{b}}$ & $1.494^{\mathrm{b}}$ & $1.648^{\mathrm{a}}$ & $1.617^{\mathrm{a}}$ & 4.27 & 0.0039 \\
\hline $\mathrm{IH}_{2} \mathrm{O}(\mathrm{mL})$ & 1976.00 & 1967.40 & 1889.82 & 1892.30 & 5.40 & 0.4181 \\
\hline $\mathrm{P} 21 \mathrm{~d}(\mathrm{~g})^{4}$ & $751.32^{\mathrm{a}}$ & $748.64^{\mathrm{a}}$ & $693.51^{\mathrm{b}}$ & $682.48^{b}$ & 3.72 & 0.0010 \\
\hline
\end{tabular}
21 (P21d) days of broiler chickens, according to the level of replacement of corn with babassu mesocarp flour.

${ }^{1}$ Variation coefficient $(\%)$.

${ }^{2}$ Test of significance ' $F$ ' of the analysis of variance.

${ }^{3}$ Means followed by the same letter in the same row do not differ by Test 'SNK' $(\mathrm{P}>0,05)$.

${ }^{4}$ Linear effect. 
Energy is one of the limiting factors of consumption and the broilers regulate their feed intake primarily to meet their energy requirements (MENDES et al., 2004). The experimental diets were formulated to be isocaloric $(2950 \mathrm{kcal} / \mathrm{kg})$ in order to meet the requirements ( $\mathrm{kcal} / \mathrm{kg}$ ) of poultry regardless of the level of substitution of corn with the BMF, which may explain the absence of effects on the feed consumption of the birds.

The birds' weight gain was lower with increasing level of replacement of corn by BMF, in accordance with to the equation: weight gain $(\mathrm{g})=719.86$ to 2.633 NS $\left(\mathrm{P}=0.0002, \mathrm{r}^{2}=0.87\right)$ where NS $=$ degree of substitution of corn with BMF (\%).

Fibres as major cell wall constituents of plant foods cannot be digested by broilers, due to evidence that broilers are resistant to hydrolysis in the digestive tract. The difficulty in fibre digestion and reduced food energy can impair the use of other nutrients (BRITO et al., 2008; TAVERNARI et al., 2008). Based on this, the increase in fibre levels in the experimental diets $(3,303,4,633,5,963$ and
7,293, Table 2) resulting from increased levels of substitution of the corn with BMF may have influenced the worsening weight gain of birds.

The lack of effect on feed intake associated with reduction in weight gain resulted in a worsening of feed conversion in accordance with the equation: feed conversion $(\mathrm{g} / \mathrm{g})=1.494+0.00483 \mathrm{NS}(\mathrm{P}=$ $\left.0.0051, r^{2}=0.65\right)$.

Even though the weight gain weight at 21 days decreased with the increasing level of replacement of corn with BMF, according to the equation: $\mathrm{P} 21 \mathrm{~d}(\mathrm{~g})=758.35$ to $2.616 \mathrm{NS}\left(\mathrm{P}=0.0002 ; \mathrm{r}^{2}=\right.$ 0.88 ), the levels of substitution of corn with BMF did not affect $(\mathrm{P}>0.05)$ the relative weights of the carcass, bursa, spleen, heart, gizzard and liver, nor the relative weight or length of the small intestine (Table 4). Divergent results were obtained by Cruz et al. (2013) who observed a reduction in the relative weight of the carcass of 8-21 days-old broiler chickens fed diets containing increasing levels of BMF.

Table 4. Weights for housing, bursa, spleen, edible giblets (heart, gizzard and liver) and a thin intestine and small intestine length $(\mathrm{cm})$ of broilers from 1 to 21 days.

\begin{tabular}{lcccccc}
\hline \multirow{2}{*}{ Variables } & \multicolumn{2}{c}{ Levels of substitution of corn for babassu mesocarp flour (\%) } & \multirow{2}{*}{ CV $^{1}$} & \multirow{2}{*}{$\mathrm{P}>\mathrm{F}^{2}$} \\
\cline { 2 - 5 } & 0 & 10 & 20 & 30 & & \\
\hline Housing (\%) & 79.20 & 79.10 & 78.75 & 78.02 & 1.57 & 0.2171 \\
Bursa (\%) & 0.32 & 0.32 & 0.38 & 0.35 & 10.86 & 0.0666 \\
Spleen (\%) & 0.11 & 0.09 & 0.11 & 0.11 & 20.53 & 0.5193 \\
Heart (\%) & 0.73 & 0.73 & 0.70 & 0.77 & 7.09 & 0.2250 \\
Gizzard (\%) & 2.42 & 2.58 & 2.80 & 2.82 & 10.94 & 0.1421 \\
Liver (\%) & 3.10 & 3.05 & 3.01 & 3.24 & 7.03 & 0.3850 \\
Small intestine (\%) & 4.72 & 4.40 & 5.11 & 5.45 & 12.25 & 0.0687 \\
Small intestine (m) & 1.36 & 1.26 & 1.32 & 1.31 & 5.18 & 0.1664 \\
\hline
\end{tabular}

${ }^{1}$ Coefficient of variation (\%).

${ }^{2}$ Test of significance ' $F$ ' of the analysis of variance.

Levels of dietary nutrients for optimal growth, weight gain and feed conversion may not be sufficient to ensure an appropriate immune response of broilers when subjected to immune challenges. Improper handling of the broilers promotes the release of high loads of corticosterone, which may cause the involution of lymphoid tissues (thymus, spleen and bursa of Fabricius) and suppression of humoral and cellular immunity (KIDD, 2004). 
In this study, the weighing of the lymphoid organs (bursa and spleen) was carried out to verify any changes that could adversely affect the productive performance and metabolism triggering inflammatory reactions and changing the lymphoid organs of these birds.

However, it was found that there was no effect $(\mathrm{P}>0.05)$ of corn being replaced by BMF in diets on the weight of the bursa and spleen, discarding the hypothesis that birds might have suffered some challenge which would trigger an immune response caused by the inclusion of BMF in diets (Table 4).

Several authors (GONZÁLEZ-ALVARADO et al., 2007, GONZÁLEZ-ALVARADO et al., 2008;. JIMÉNEZ-MORENO et al., 2009;. JIMÉNEZMORENO et al., 2010; SACRANIE et al., 2012) confirmed in their studies that the presence of high levels of fibre in the diet stimulated the development of the digestive organs, resulting in greater weight of the gizzard and of some segments of the small intestine. In the present study the experimental diets had higher levels of crude fibre, neutral detergent fibre, and acid detergent fibre, ranging from 3.3 to $7.3 \% ; 13.4$ to $18.9 \%$ and from 4.5 to $8.9 \%$, respectively. Therefore it was expected that there would be changes in the weight of the digestive organs. However, this hypothesis was not confirmed given the absence of effects on the digestive organs.

The coefficients of apparent metabolizability dry matter (MCDM) and gross energy (MCGE) of balanced rations were affected $(\mathrm{P}<0.05)$ by the replacement of corn with BMF had no effect $(\mathrm{P}>$ $0.05)$ on the apparent metabolizability coefficient crude protein (MCCP) (Table 5). The MCDM (\%) of diets reduced as the level of replacement of corn with BMF increased, in accordance with the equation: $\operatorname{MCDM}(\%)=77.03$ to $0.2367 \mathrm{NS}\left(\mathrm{P}=0.0001, \mathrm{r}^{2}=\right.$ $0.99)$, where NS = degree of substitution corn with BMF (\%).

Table 5. Metabolizability coefficients apparent of dry matter (MCDM), crude protein (MCCP) and gross energy (MCGE) of experimental diets.

\begin{tabular}{lcccccc}
\hline \multirow{2}{*}{ Variables } & \multicolumn{2}{c}{ Levels of substitution of corn with babassu mesocarp flour (\%) } & \multirow{2}{*}{$\mathrm{CV}^{1}$} & \multirow{2}{*}{$\mathrm{P}>\mathrm{F}^{2}$} \\
\cline { 2 - 4 } MCDM (\%) & 0 & 10 & 20 & 30 & & \\
MCCP (\%) & $77.09^{\mathrm{a}}$ & $74.48^{\mathrm{b}}$ & $72.51^{\mathrm{b}}$ & $69.86^{\mathrm{c}}$ & 2.35 & 0.0001 \\
MCGE (\%) & 70.43 & 71.55 & 71.67 & 73.16 & 2.58 & 0.1824 \\
\hline
\end{tabular}

${ }^{1}$ Coefficient of variation (\%).

${ }^{2}$ Test of significance ' $F$ ' of the analysis of variance.

${ }^{3}$ Linear effect.

In a similar way to the MCDM, the MCGE $(\%)$ of diets reduced with the increasing level of replacement of corn with $\mathrm{BMF}$, in accordance with the equation: $\operatorname{MCGE}(\%)=78.16$ to $0.1974 \mathrm{NS}(\mathrm{P}=$ $\left.0.0001, r^{2}=0.99\right)$.

Cavalcante Neto (2012) conducted detailed laboratory analysis of the fibre fraction BMF, detecting values of $12.85 \%$ soluble fibre and $3.09 \%$ of insoluble fibre, classifying this ingredient as an especially soluble source of fibre. It is known that soluble fibres are able to bind large quantities of water, thereby increasing the viscosity of the gastrointestinal contents making them less available for nutrient digestion and resulting in a lower utilization of nutrients. Reducing the MCDM and the MCGE may have been the result of increasing levels of fibres in the experimental diets (Table 2), which resulted in the worsening of the WP, FI and $\mathrm{P} 21 \mathrm{~d}$ of birds with the increased level of replacement of corn with BMF.

The use of up to $10 \%$ replacement of corn with the BMF is technically feasible in balanced diets 
for broilers from 1 to 21 days when the nutritional requirements of the broilers are met.

We observed that the substitution of corn with $\mathrm{BMF}$ in the diets caused a linear reduction in the cost of the experimental diets, taking into account the price of inputs used in experimental diets. The lower cost of feed per kg of WG was obtained with the diet containing $10 \%$ corn replacement with BMF which resulted in a higher gross margin compared to food (Table 6).

Table 6. Cost of power $(£ / \mathrm{kg})$, feed cost per $\mathrm{kg}$ weight gain $(£ / \mathrm{kg})$, gross margin in relation to food $(£ / \mathrm{kg})$ of broilers from 1 to 21 days.

\begin{tabular}{lcccc}
\hline \multirow{2}{*}{ Variables } & \multicolumn{3}{c}{ Levels of substitution of corn with babassu mesocarp flour (\%) } \\
\cline { 2 - 4 } & 0 & 10 & 20 & 30 \\
\hline Weight gain $(\mathrm{g})$ & 713.12 & 710.44 & 653.61 & 644.28 \\
Cost of power1 $(£ / \mathrm{kg})$ & 1.091 & 1.071 & 1.051 & 1.031 \\
Cost of feed per kg of WG $(£ / \mathrm{kg})$ & 1.641 & 1.599 & 1.695 & 1.666 \\
Gross margin $(£ / \mathrm{kg})$ & 1.209 & 1.251 & 1.155 & 1.184 \\
\hline
\end{tabular}

${ }^{1}$ Considering the following prices used in March 2012: Corn $=£ 0.59 / \mathrm{kg}$; Soybean meal $=£ 1.30 / \mathrm{kg}$; Babassu mesocarp flour $=£$ $0.22 / \mathrm{kg} ;$ Starch $($ Cornstarch $)=£ 2.70$; Dicalcium phosphate $=£ 2.77 / \mathrm{kg}$; Soybean oil $=£ 2.49 / \mathrm{kg} ; \mathrm{Limestone}=£ 0.43 / \mathrm{kg} ; \mathrm{Salt}$ $=0.80 \mathrm{~kg} ; \mathrm{DL}-$ methionine $=£ 11.87 / \mathrm{kg} ; \mathrm{L}$-lysine $\mathrm{HCl}=£ 6.67 / \mathrm{kg}$; L-threonine $=£ 6.76 / \mathrm{kg}$; Mineral and vitamin supplement $=£ 9.00 / \mathrm{kg}$.

${ }^{2}$ Considering the price of live chicken on $03 / 04 / 2012$ paid $£ 2.85 / \mathrm{kg}$ by the company Asa Norte Food.

In general, the results of this study showed that replacing $10 \%$ of the corn with $\mathrm{BMF}$ in the diets of broilers aged 1-21 days old is technically and economically feasible since this substitution resulted in a similar performance as the default diet (without BMF), a lower cost per $\mathrm{kg}$ of $\mathrm{WG}$ ration and a higher gross margin in relation to food.

Because the BMF has a lower nutritional value than corn, it is emphasized that replacing $10 \%$ of the corn with BMF should be performed with concomitant supplementation of synthetic amino acids (L-lysine $\mathrm{HCl}$, DL-methionine and L-threonine) and vegetable oil so that the broilers nutritional requirements are met.

Using the BMF to replace $10 \%$ of the corn in the diets of broilers from 1 to 21 days will be subject to the price of these inputs.

\section{Conclusion}

The replacement of $10 \%$ of the corn with babassu mesocarp flour proved both technically and economically feasible in balanced diets for male broilers aged $1-21$ days old.

\section{References}

AMORIM, E.; MATIAS, J. E. F.; COELHO, J. C. U.; CAMPOS, A. C. L.; STAHLKE, J. R.; H. J; TIMI, J. R. F.; ROCHA, L. C. A.; MOREIRA, A. T. R.; RISPOLI, D. Z.; FERREIRA, L. M. A. Efeito do uso tópico do extrato aquoso de Orbignya phalerata (Babaçu) na cicatrização de feridas cutâneas - estudo controlado em ratos. Revista Acta Cirúrgica Brasileira, São Paulo, v. 21, p. 67-66, 2006. Suplemento 2.

BARROQUEIRO, E. S. B.; BARROQUEIRO, F. S. B.; PINHEIRO, M. T.; MACIEL, M. C. G.; BARCELOS, O. S.; SILVA, L. A.; LOPES, A. S.; NASCIMENTO, F. R. F.; GUERRA, R. N. M. Evaluation of acute toxicity of babassu mesocarp in mice. Brasilian Journal of Phamacognosy, Curitiba, v. 21, n. 4, p. 710-714, 2011.

BRITO, M. S.; OLIVEIRA, C. F. S.; SILVA, T. R. G.; LIMA, R. B.; MORAIS, S. N.; SILVA, J. H. V. Polissacarídeos não amiláceos na nutrição de monogástricos - revisão. Revista Acta Veterinária Brasílica, Mossoró, v. 2, n. 4, p. 111-117, 2008.

CARNEIRO, A. P. M.; PASCOAL, L.A. F.; WATANABE, P. H.; SANTOS, I. B.; LOPES, J. M.; ARRUDA, J. C. B. Farelo de babaçu em rações para frangos de corte na fase final: desempenho, rendimento de carcaça e avaliação econômica. Revista Ciência Animal Brasileira, Goiânia, v. 10, n. 1, p. 40-47, 2009.

CAVALCANTE NETO, A. A. Desenvolvimento de massa alimentícia mista de farinhas de trigo e mesocarpo de 
babaçu (Orbignya sp). 2012. Dissertação (Mestrado em Ciência e Tecnologia de Alimentos) - Universidade Federal Rural do Rio de Janeiro, Rio de Janeiro.

CRUZ, L. A.; VAZ, R. G. M. V.; SIQUEIRA, J. C.; SILVA, G. F. C; RODRIGUES, K. F.; STRINGHINI, J. H.; RAMOS, A. T.; SOUSA, J. P. G. de; CALIXTO, M. S.; FONSECA, F. L. R. Farinha do mesocarpo do babaçu em rações de frangos de corte na fase inicial. Archivos de Zootecnia, Córdova, v. 62, n. 240, p. 525-532, 2013.

GONZÁLEZ-ALVARADO, J. M.; JIMÉNEZMORENO, E.; LAZÁRO, R.; MATEO, G. G. Effect of type of cereal, heat processing of the cereal, and inclusion of fiber in the diet on productive performance and digestive traits of broilers. Poultry Science, Champaign, v. 86, n. 8, p. 1705-1715, 2007.

GONZÁLES-ALVARADO, J. M.; JIMÉNEZ-MORENO, E.; VALENCIA, D. G.; LÁZARO, R.; MATEOS, G. G. Effects of fiber source and heat processing of the cereal on the development and $\mathrm{pH}$ of the gastrointestinal tract of broilers fed diets based on corn or rice. Poultry Science, Champaign, v. 87, n. 9, p. 1779-1795, 2008.

JIMÉNEZ-MORENO, E.; GONZÁLEZ-ALVARADO, J. M.; GONZÁLEZ-SERRANO, A.; LAZÁRO, R.; MATEOS, G. G. Effect of dietary fiber and fat on performance and digestive traits of broilers from one to twenty-one days of age. Poultry Science, Champaign, v. 88, n. 12, p. 2562-2574, 2009.

Effects of type and particle size of dietary fiber on growth performance and digestive traits of broilers from 1 to 21 days of age. Poultry Science, Champaign, v. 89, n. 10, p. 2197-2212, 2010.

JESUS JUNIOR, C.; PAULA, L. R. S.; ORMOND, P. G. J.; BRAGA, M. N. A Cadeia da carne de frango: tensões, desafios e oportunidades. Agroindústria, Rio de Janeiro, v. 1, n. 26, p. 191-232, 2007.

KIDD, M. T. Nutritional modulation of immune fuction in broilers. Poultry Science, Champaign, v. 83, n. 4, p. 650-657, 2004.

MENDES, A. A.; MOREIRA, J.; OLIVEIRA, E. G.; GARCIA, E. A.; ALMEIDA, M. I. M.; GARCIA, R. G. Efeitos da energia da dieta sobre desempenho, rendimento de carcaça e gordura abdominal de frangos de corte. Revista Brasileira de Zootecnia, Viçosa, v. 33, n. 6, p. 2300-2307, 2004. Suplemento 3.

OLIVEIRA, R. F. M.; DONZELE, J. L.; ABREU, M. L. T.; FERREIRA, R. A.; VAZ; R. G. M. V.; CELLA, P. S. Efeitos da temperatura e umidade relativa sobre o desempenho e o rendimento de cortes nobres de frango de corte de 1 a 49 dias de idade. Revista Brasileira de Zootecnia, Viçosa v. 35, n. 3, p. 797-803, 2006.
PAVLAK, M. C. M.; ZUNIGA, A. D.; LIMA, T. L. A.; ARÉVALO-PINEDO, A.; CARREIRO, S. C.; FLEURY, C. S.; SILVA, D. L. Aproveitamento do farelo do mesocarpo do babaçu (Orbignya martiana) para obtenção de etanol. Revista Evidência, Joaçaba, v. 7, n. 1, p. 7-24, 2007.

ROSTAGNO, H. S.; ALBINO, L. F. T.; DONZELE, J. L.; GOMES, P. C.; OLIVEIRA, R. F.; LOPES, D. C.; FERREIRA, A. S.; BARRETO, S. L. T. Tabelas brasileiras para aves e suinos composição de alimentos e exigências nutricionais. 3. ed. Viçosa: UFV, Imprensa Universitária, 2011. 252 p.

SACRANIE, A.; SVIHUS, B.; DENSTADLI, V.; MOEN, B.; IJI, P. A.; CHOCT, M. The effect of insoluble fiber and intermittent feeding on gizzard development, gut motility, and performance of broiler chickens. Poultry Science, Champaign, v. 91, n. 3, p. 693-700, 2012.

SAKOMURA, N. K.; ROSTAGNO, H. S. Métodos de pesquisa em pesquisa em nutrição de monogástricos. Jaboticabal: UNESP, 2007. 283 p.

SANTOS, A. P. S.; SOUSA, G. F.; FREITAS, R. M.; NUNES, L. C. C. Avaliação da toxicidade aguda do extrato aquoso do pó do mesocarpo de Orbignya phalerata Mart (Babaçu). Revista Cubana de Plantas Medicinales, Havana, v. 17, n. 4, p. 393-401, 2012.

SANTOS NETA, E. R. Avaliação de subprodutos do babaçu (Palmae orbignya martiana) na alimentação de frangos de corte. 2010. Dissertação (Mestrado em Ciência Animal Tropical) - Universidade Federal do Tocantins, Araguaína.

SANTOS NETA, E. R.; VAZ, R. G. M. V.; RODRIGUES, K. F.; SOUSA, J. P. L.; PARENTE, I. P.; ALBINO, L. F. T.; SIQUEIRA, J. C.; ROSA, F. C. Níveis de inclusão da torta de babaçu em rações de frangos de corte na fase inicial. Revista Brasileira de Saúde e Produção Animal, Salvador, v. 12, n. 1, p. 234-243, 2011.

SILVA, D. J.; QUEIROZ, A. C. Análise de alimentos, métodos químicos e biológicos. 3. ed. Viçosa: UFV. 2002. $165 \mathrm{p}$.

STATISTICAL ANALYSIS SYSTEM - SAS - System for linear models. Cary: SAS Institute. 2002. 211 p.

TAVERNARI, F. C.; CARVALHO, T. A.; ASSIS, A. P.; LIMA, H. J. D’A. Polissacarídeo não amiláceo solúvel na dieta de suínos e aves. Revista Eletrônica Nutritime, Viçosa, v. 5, n. 5, p. 673-689, 2008. 